Rajeev Chawla ${ }^{1}$, Minakshisundaram Shunmugavelu², Brij Makkar ${ }^{3}$, Manoj Chawla ${ }^{4}$ Abhay Sahoo ${ }^{5}$, Sujoy Majumdar ${ }^{6}$, Sailesh Lodha7, Sunil Gupta ${ }^{8}$, Anil Bhansali ${ }^{9}$

${ }^{1}$ North Delhi Diabetes Centre, Rohini, Delhi, Maharaja Agrasen Hospital, New Delhi, India

${ }^{2}$ Chairman, Trichy Diabetes Speciality Centre (P) Ltd, Trichy, Tamil Nadu, India

${ }^{3}$ Diabetes \& Obesity Center, New Delhi, India

${ }^{4}$ Lina Diabetes Care Center, Mumbai, India

${ }^{5}$ Department of Endocrinology, IMS and SUM Hospital and Medical College, Bhubaneshwar, India

${ }^{6} \mathrm{GD}$ hospital and Diabetes Institute, Kolkata, India

${ }^{7}$ Department of Endocrinology, Fortis Hospital, Jaipur, India

${ }^{8}$ Sunil's Diabetes Care n' Research Centre, Nagpur, India

${ }^{9}$ Department of Endocrinology, Postgraduate Institute of Medical Education and Research, Chandigarh, India

\title{
Practical guidance on insulin injection practice in diabetes self-management in the Indian setting: an expert consensus statement
}

\section{ABSTRACT}

This consensus statement aimed to provide a simple and easily implementable practical educational guideline for healthcare professionals (HCPs) and patients regarding insulin injection practice in diabetes selfmanagement in the Indian setting.

A group of experts analysed published data from guidelines, clinical trials and real world evidence to reach consensus recommendations on optimal insulin injection practices in terms of a) the injection sites (preparation of site of injection, choosing the injection site, site rotation), b) choice of device and storage of insulins, and c) safety precautions, sharp disposal practice and complications.

Findings from Global and Indian arm of 2014-2015 ITQ Study were considered to emphasize a need for improved practice by HCPs covering all the vital topics essential to proper injection habits.

Address for correspondence:

Dr Rajeev Chawla

North Delhi Diabetes Centre, Rohini, Delhi

Maharaja Agrasen Hospital, New Delhi, India

Mobile number: 09811799666

e-mail: rajeevaastikchawla@yahoo.com

Clinical Diabetology 2019, 8, 3, 176-194

DOI: $10.5603 /$ DK.2019.0013

Received: 25.10.2018

Accepted: 21.01.2019
The consensus statement provides a simple and easily implementable practical educational guideline for HCPs and patients to optimize insulin injection practices in accordance with recent advances in device manufacturing, newer research findings, and updated international guidelines as well as widespread concerns about neglected safety precautions such as single-patient use of pens and appropriate sharp disposal practices. (Clin Diabetol 2019; 8, 3: 176-194)

Key words: insulin injection practices, guidelines, injection site, site rotation, storage, disposal, safety, complications

\section{Introduction}

Insulin self-administration is an indispensable component of diabetes management and the importance of guiding patients towards best injection practice has increasingly been recognized in accordance with growing awareness of the critical role of the correct injection technique in achieving optimal control of diabetes [1-7].

Incorrect selection of injection site or delivery device and inappropriate injection technique are considered to modify insulin absorption parameters, leading 
to higher amount of insulin use and higher glycated haemoglobin $\left(\mathrm{HbA}_{1 \mathrm{c}}\right)$ values as well as to glycaemic variability, unexplained hypoglycaemia and poor longterm outcomes [8-10]. Therefore, correct insulin injection technique and correct choice of injection site and delivery devices have been considered as important as providing optimal (type and dose) insulin therapy in achievement of glycaemic goal in diabetes $[5,11]$.

Identification of patient, provider, and healthcare system based barriers of initiating and adhering to insulin injection therapy is a critical step toward successful diabetes self-management [5, 12-16]. Optimal delivery and effect of all injectable agents rely on correct injection technique [17], emphasizing the role of enhanced awareness of the good injection practices among healthcare professionals (HCPs) as well as patients $[5,9,18]$. Several guidelines on insulin self-administration are available across the world as well as in India, whereas as consistently reported by several studies across the globe, there is a significant gap between the recommendations of the guidelines and actual insulin injection practice [5, 8, 10, 19-21].

Moreover, recent advances in device manufacturing, newer research findings and updated international guidelines necessitate renewed commitment toward optimizing insulin injection practices [5].

Therefore, this consensus statement aimed to review the current guidelines and available evidence to provide a simple and easily implementable practical educational guideline on insulin injection practice for both HCPs and patients in terms of preparation and selection of injection sites, site rotation, selection of the device, storage of insulins, safety precautions, sharp disposal practice and complications.

\section{Materials and methods}

An expert panel consisting of 9 endocrinology specialists from university and state hospitals met to develop consensus on insulin injection practices in insulin-treated patients with diabetes in the Indian setting. The panel critically analysed published data from guidelines, clinical trials and real world evidence and agreed on a series of recommendations supported by scientific evidence and experts' clinical opinion. The proposed consensus planned to provide a simple and easily implementable practical educational guideline for insulin injection practice for both HCPs and patients, in terms of a) the injection sites (preparation of site of injection, choosing the injection site, site rotation), b) choice of device and storage of insulins, and c) safety precautions, sharp disposal practice and complications (Figure 1).

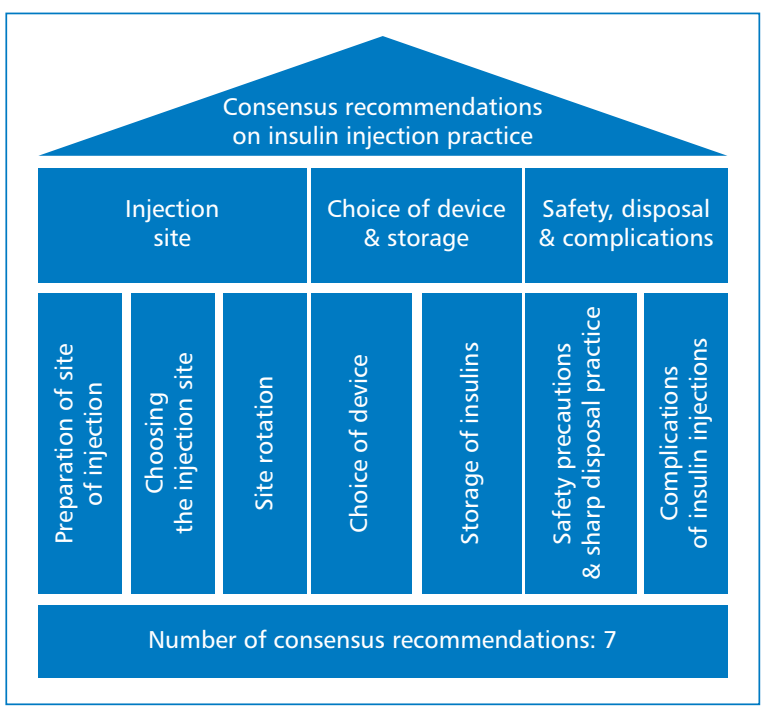

Figure 1. Framework for consensus recommendations

\section{Injection site}

Injection site preparation

Current guideline recommendation on injection site preparation indicates the injection site should be clean and dry, and soap and water can therefore be used for unclean sites with no need for disinfection, whereas whenever use of alcohol swabs is needed, the site should be dried before injecting (Table 1) [5, 22-25]. However, disinfection is required in institutional settings such as hospitals and nursing homes, particularly if the site is found to be unclean. If alcohol is used, it must be allowed to dry completely before the injection is given [26].

\section{Consensus statement on injection site preparation}

The expert panel recommends that the injection must be given to clean site using clean hands and after inspection and palpation, with use of soap and water when it is necessary to clean the site of injection. Disinfection of the site or the device is not recommended, while if alcohol swabs are used, then the area must be allowed to dry before the injection.

Consensus statement 1 . Injection site preparation

- Injection must be given to clean site using clean hands

- Disinfection of the site or the device is not recommended

- Cleaning of the site of injection with soap and water can be done

- If alcohol swabs are used, then the area must be allowed to dry before the injection

- The site should be inspected and palpated by the individual prior to injection 
Table 1. Guidelines recommendations on injection site preparation

\begin{tabular}{|c|c|}
\hline Guideline & Recommendation \\
\hline Canadian Forum of Injection techniques (FIT) & - Site should be clean and free of infection, oedema, bruising or lipohypertrophy \\
\hline Recommendations for Best Practice in Injection & - Alcohol swabs may be used, but should be dried before injecting \\
\hline \multicolumn{2}{|l|}{ Technique (2012) [22] } \\
\hline UK FIT Recommendations for Best Practice & - Site inspection and palpation before use \\
\hline \multirow[t]{4}{*}{ in Injection Technique (2015) [23] } & - Avoid site with infection, lipohypertrophy, inflammation \\
\hline & - Inject in clean site with clean hands \\
\hline & - If unclean - use soap and water \\
\hline & - Disinfection usually not required; alcohol swabs may be used \\
\hline American Association of Diabetes Educators & - Site should be clean and dry \\
\hline (AADE) Strategies for Insulin Injection Therapy & - Injection through single layer of clothing — clinical judgment \\
\hline \multicolumn{2}{|l|}{ in Diabetes Self-Management (2011) [24] } \\
\hline American Diabetes Association (ADA) Insulin & - Wait until topical alcohol (if used) has evaporated completely before injection \\
\hline \multicolumn{2}{|l|}{ Administration Guidelines (2004) [25] } \\
\hline Australian Diabetes Educators Association & - If site requires cleaning, soap and water is adequate \\
\hline (ADEA) Clinical Guiding Principles for & - Alcohol usually not required, increases skin toughening \\
\hline \multicolumn{2}{|l|}{ Subcutaneous Injection Technique (2015) [26] } \\
\hline Indian FIT Recommendations for Best Practice & - Clean site properly \\
\hline \multirow[t]{3}{*}{ in Injection Technique (2017) [5] } & - Alcohol if used, let it evaporate, as dry surface minimizes pain \\
\hline & - Do not use soap-based detergent, chloroxylenol, and cetrimide/chlorhexidine \\
\hline & - Inject if site is considered "socially clean" \\
\hline
\end{tabular}

\section{Choosing the injection site}

Rate of insulin absorption depends on multiple factors including insulin related factors (physicochemical properties, excipients, injected volume, concentration, and dosage) and the clinical conditions during injection [orthostatic position, injection site, depth of injection, exercises, local massage, heat exposure, smoking, subcutaneous tissue thickness (SCT) and subcutaneous adipose tissue blood flow] [27-29].

Overall, gender (higher risk in males), BMI (higher risk for $<25 \mathrm{~kg} / \mathrm{m}^{2}$ ), and injection site (higher risk for thigh) as combined with needle length (higher risk for $\geq 8 \mathrm{~mm}$ ) and insertion angle $\left(90^{\circ}\right)$, are considered to determine estimates of risk of intramuscular insulin injection [30-32].

Abdomen and buttock are the site of injections associated with fastest and slowest rates of insulin absorption, respectively, while lateral side of the thigh, not proximal to the knee, and upper arm have moderate absorption rates [25, 33-35].

Available guidelines on insulin injection practice consider abdomen as the commonest injection site followed by buttocks and thigh $[5,22,23]$ or arm, [24-26] and recommend selection of thigh [5, 23, 24, $26]$ and buttocks $[5,23,26]$ for NPH, abdomen for soluble human insulin, $[23,26]$ abdomen (morning) and thigh or buttock (evening) for premixed insulins [23], while no specific site selection was considered for insulin analogues $[23,26]$ (Table 2).

\section{Consensus statement on injection site selection}

The expert panel recommends that abdomen (the site with the most consistent absorption) as followed by thighs and buttocks as the appropriate injection sites for adults, whereas the arm is not considered a preferred site for self-injection due to risk of intramuscular administration. Abdomen is considered to be potentially better choice of injection site for soluble human insulin due to characteristic fastest absorption, while thigh and buttocks are considered more appropriate for NPH injection since absorption is slowest from these sites. For rapid or long acting basal insulin analogues and GLP 1agonists, using any of the injection sites is possible as absorption rates do not appear to be site-specific.

\section{Consensus statement 2. Injection site selection}

- Abdomen, thighs and buttocks are the recommended injection sites for adults, with abdomen offering most consistent absorption

- The arm is not a preferred site for self-injection due to risk of intramuscular administration

- The thigh and buttocks may be preferred injection sites when using the NPH, since absorption is slowest from these sites

- The abdomen may be the preferred site for soluble human insulin since absorption is fastest there 
Table 2. Guideline recommendations on injection site selection

\begin{tabular}{|c|c|}
\hline Guideline & Recommendation \\
\hline Canadian FIT Recommendations for Best & - Abdomen, thighs and buttocks are the recommended sites \\
\hline Practice in Injection Technique (2012) [22] & $\begin{array}{l}\text { - Abdomen - most consistent absorption } \\
\text { - Arm not preferred — difficult access, less SC fat and } \uparrow \text { risk of IM injection }\end{array}$ \\
\hline $\begin{array}{l}\text { UK FIT Recommendations for Best Practice } \\
\text { in Injection Technique (2015) [23] }\end{array}$ & $\begin{array}{l}\text { - Thigh and buttocks - preferred for NPH } \\
\text { - Abdomen preferred - soluble human insulin } \\
\text { - Premixed insulin - abdomen (morning) and thigh or buttock (evening) } \\
\text { - Insulin analogues - any site }\end{array}$ \\
\hline $\begin{array}{l}\text { American Association of Diabetes Educators } \\
\text { (AADE) Strategies for Insulin Injection Therapy } \\
\text { in Diabetes Self-Management (2011) [24] }\end{array}$ & $\begin{array}{l}\text { - Thigh }-\mathrm{NPH} \\
\text { - Absorption fastest - abdomen }>\text { arms }>\text { thighs }>\text { buttocks }\end{array}$ \\
\hline $\begin{array}{l}\text { American Diabetes Association (ADA) Insulin } \\
\text { Administration Guidelines (2004) [25] }\end{array}$ & $\begin{array}{l}\text { - Upper arm \& anterior and lateral aspects of thigh, buttocks, and abdomen } \\
\text { (exception - circle with 2-inch radius around the navel) }\end{array}$ \\
\hline $\begin{array}{l}\text { Australian Diabetes Educators Association } \\
\text { (ADEA) Clinical Guiding Principles for Subcuta- } \\
\text { neous Injection Technique (2015) [26] }\end{array}$ & $\begin{array}{l}\text { - Abdomen - commonest site followed by buttocks, thigh and arm } \\
\text { - Abdomen - no injection within } 5 \mathrm{~cm} \text { of umbilicus } \\
\text { - Human insulin - abdomen, NPH - thigh and buttocks } \\
\text { - Modern analogue insulin - any site } \\
\text { - GLP-1 - abdomen, thigh or upper arm }\end{array}$ \\
\hline $\begin{array}{l}\text { Indian FIT Recommendations for Best Practice } \\
\text { in Injection Technique (2017) [5] }\end{array}$ & $\begin{array}{l}\text { - Indian women - discuss site beforehand, so that their sensibilities are not } \\
\text { offended } \\
\text { - Abdomen preferred } \\
\text { - If risk of nocturnal hypoglycaemia with NPH - evening dose into thigh or buttock } \\
\text { - Buttock - for infants and toddlers, not preferred in adults }\end{array}$ \\
\hline
\end{tabular}

- Rapid-acting and long acting basal insulin analogues may be given at any of the injection sites, as absorption rates do not appear to be site-specific

- When injecting rapid and long acting analogue insulin these should be given in different sites even if given at different times during the day

- Injection site showing signs of oedema, inflammation must be avoided

- GLP 1 agonists are absorbed equally from each of the usual injection sites (abdomen, arm and thigh)

\section{Site rotation}

Correct site rotation, defined as always injecting at least $1 \mathrm{~cm}$ from a previous injection, has been consistently shown to be the best way to safeguard normal tissue $[4,34,36,37]$.

Worldwide Injection Technique Questionnaire (ITQ) 2014-2015 data reported that patients who rotate correctly tend to have lesser rates for hyperglycaemia, LH, unexplained hypoglycaemia and glucose variability $[10,38]$. Incorrect rotation of sites was reported to be associated with $0.57 \%$ higher $\mathrm{HbA}_{1 \mathrm{c}}$ levels, $4.7 \mathrm{IU}$ higher total daily insulin dose and higher frequencies of unexpected hypoglycaemia and glucose variability [10, 38].

In a recent study comparing findings from Indian arm vs. rest of the world (ROW) in the ITQ
2014-2015 global study, correct site rotation was reported to be applied by similar percentage of patients in the India setting (68.1\%) and rest of the world (ROW) (71.0\%), whereas much higher percentage of patients in India than in ROW (48.7 vs. $18.4 \%$ ) identified that they were never trained on correct site rotation [36].

Notably, despite its association with lower $\mathrm{HBA}_{1 \mathrm{c}}$ levels, less $\mathrm{LH}$, and more correct injection site rotation; routine inspection of injection sites by the HCP at least once a year was not met by nearly $80 \%$ of patients in India as well as in ROW $[36,38]$.

Implementation of an easy-to-follow rotation scheme from the onset of injection therapy is considered important in acquisition of an appropriate site rotation practice. One scheme with proven effectiveness involves dividing the injection site into quadrants (or halves when using the thighs or buttocks), using one quadrant per week and moving always clockwise. Injections within any quadrant or half should be spaced at least $1 \mathrm{~cm}$ from each other in order to avoid repeat tissue trauma. Pump cannula should be placed at least $3 \mathrm{~cm}$ away from previous sites. HCPs should verify that the rotation scheme is being followed at each visit and give help and advice where needed (Figure 2, 3) [4, 36, 39-41]. 


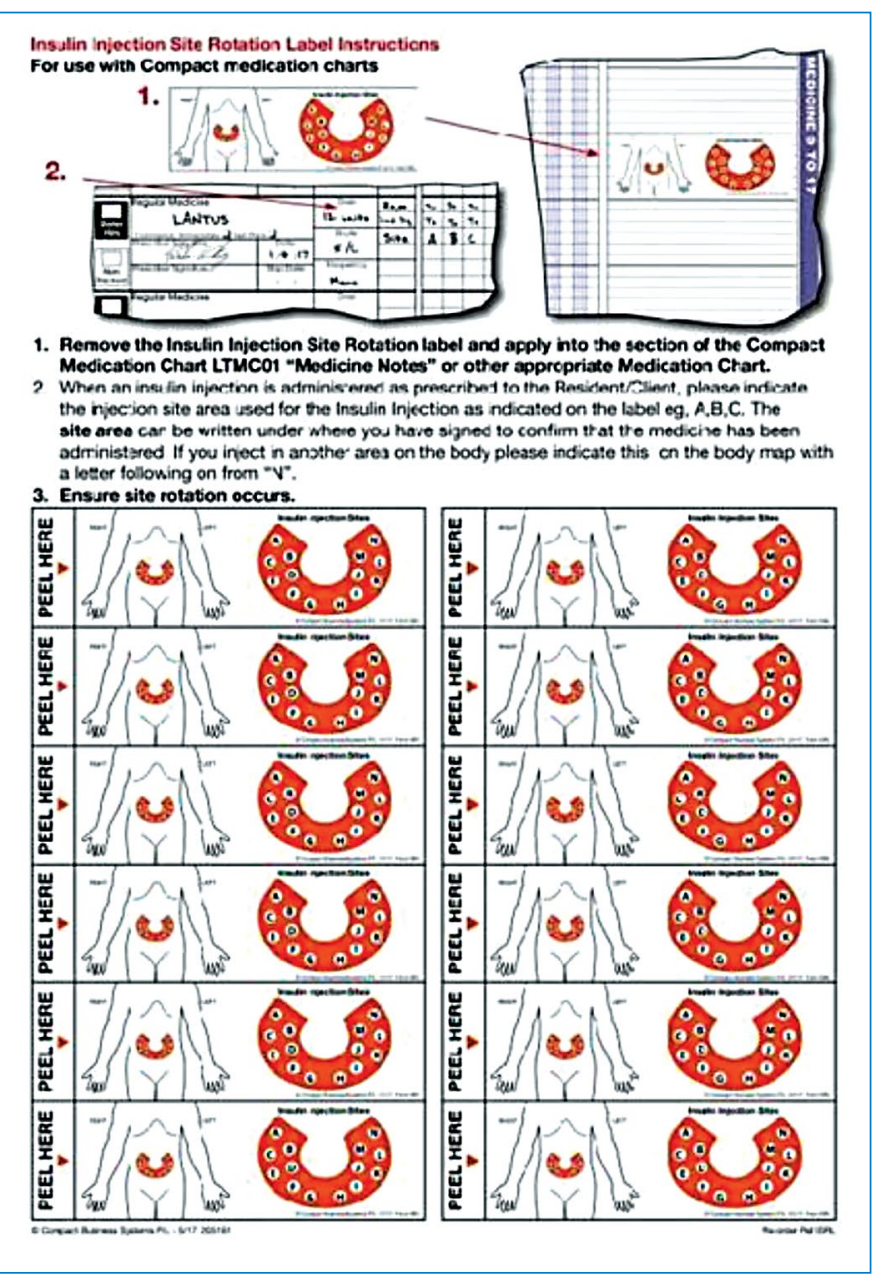

Figure 2. Insulin injection site rotation label

Available guidelines on site rotation recommend teaching a structured and easy-to-follow rotation scheme to patients, and emphasize rotating within one area rather than rotating to a different area and with dividing the injection site into quadrants (abdomen) or halves (buttock or thigh), using 1 quadrant/week and moving clockwise and spacing injections at least 1 $\mathrm{cm}$ from each other. Patient education and inspection at each visit is considered essential, while use of site rotation grids is considered useful in patients forgetting injection sites (Table 3) [5, 22-26, 42].

\section{Consensus statement on site rotation}

The expert panel recommends teaching an easyto-follow rotation scheme to patients from the onset of injection therapy, use of a structured rotation plan including one quadrant per week and moving always in the same direction with spacing subsequent injections within the quadrant at $1 \mathrm{~cm}$ to avoid repeated trauma and review and emphasize the importance of discussing site rotation with patient at each visit.

\section{Consensus statement 3. Site rotation}

- Individuals should be taught an easy-to-follow rotation scheme from the onset of injection therapy

- Structured rotation plan of one quadrant per week and moving always in the same direction is proven and effective

- Injection within the quadrant must be spaced at $1 \mathrm{~cm}$ to avoid repeated trauma

- Site rotation at each injection is the most appropriate strategy for prevention of lipohypertrophy. It also ensures consistent absorption

- It is recommended to discuss the rotation of site with patient during each visit

\section{Choice of device and storage of insulins}

Selection of the device

Factors underlying the choice of right device include biomechanical factors (accuracy, length of needle, degree of dose increment and suitability for children/visually/dexterity-challenged people), psychosocial factors (attractiveness, discreteness/ 


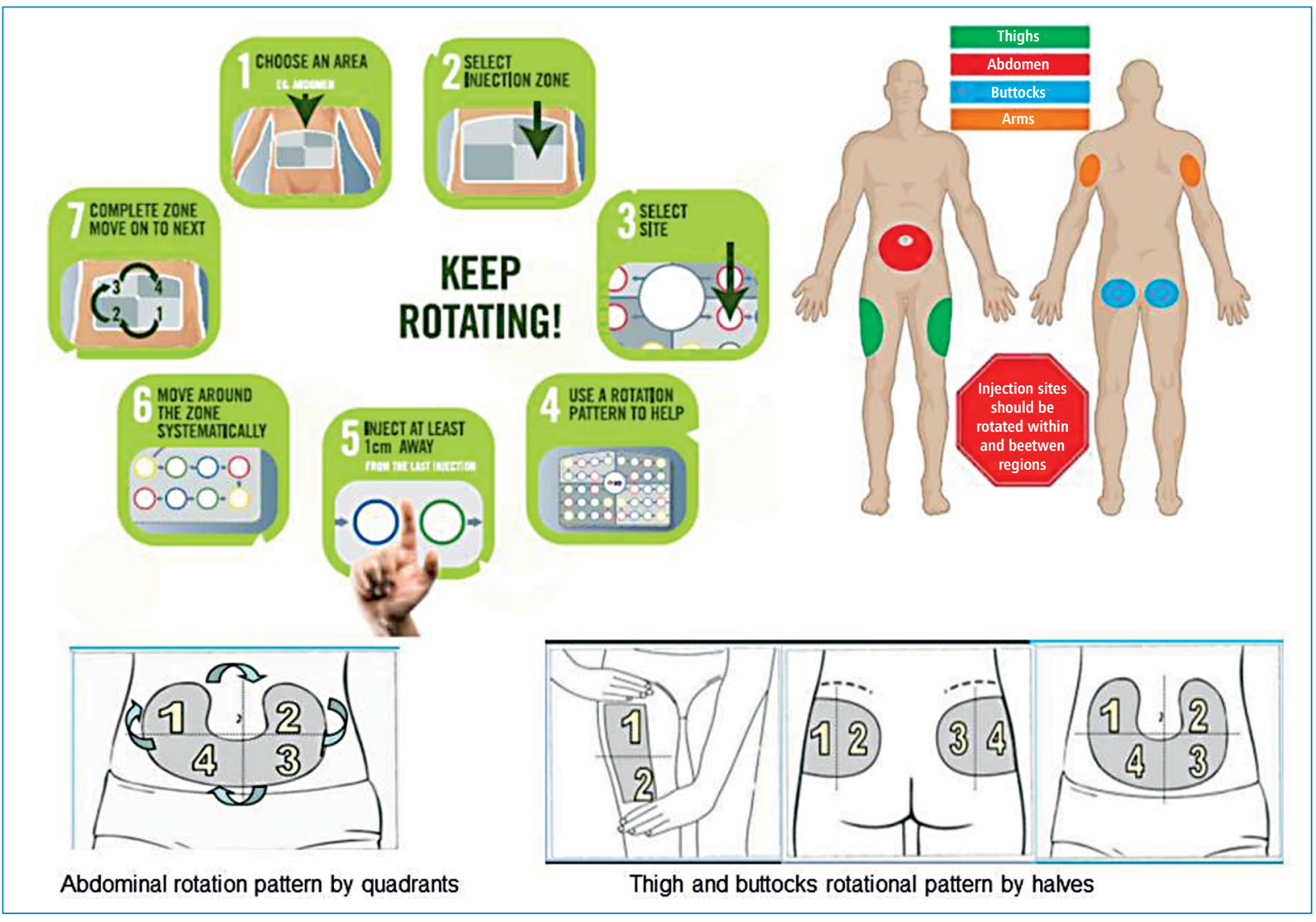

Figure 3. Ways for optimal site rotation. Adapted from Frid A. et al. Diabetes and Metabolism 2010; 36 (Suppl 2): S3-18, Kaira et al. Diabetes Ther. 2017; 8: 659-672. Diagrams courtesy of Lourdes Saez-de Ibarra and Ruth Gaspar, DNSPE from La Paz Hospital, Madrid, Spain, Spollett G. et al. The Diabetes Educator 2016; 42 (4): 379-394

Table 3. Guideline recommendations on site rotation

\begin{tabular}{|c|c|}
\hline Guideline & Recommendation \\
\hline Canadian FIT Recommendations for Best & - Teach \& demonstrate "structured rotation" to patient \\
\hline Practice in Injection Technique (2012) [22] & $\begin{array}{l}\text { - Same anatomical region, same time of day, } 2 \text { to } 3 \mathrm{~cm} \text { apart injections } \\
\text { - Rotation of site - discuss and check at each patient visit }\end{array}$ \\
\hline UK FIT Recommendations for Best Practice & - Teach easy-to-follow rotation scheme at onset of therapy \\
\hline in Injection Technique (2015) [23] & $\begin{array}{l}\text { - Divide site into quadrants, } 1 \text { quadrant/week, move always in same direction } \\
\text { (clockwise or anti-clockwise) } \\
\text { - Space injections at least } 1 \mathrm{~cm} \text { from each other } \\
\text { - Teach and demonstrate for detection of lipohypertrophy }\end{array}$ \\
\hline American Association of Diabetes Educators & - Rotation within an area - critical for optimal absorption \\
\hline (AADE) Strategies for Insulin Injection Therapy & - Rotation - within the same area, rather than from major site to site \\
\hline in Diabetes Self-Management (2011) [24] & - Patient education and inspection at each visit essential \\
\hline American Diabetes Association (ADA) Insulin & - Rotation - important to prevent lipohypertrophy \\
\hline Administration Guidelines (2004) [25] & $\begin{array}{l}\text { - Rotate within one area rather than rotating to a different area } \\
\text { - Helps to decrease variability in absorption from day to day }\end{array}$ \\
\hline Australian Diabetes Educators Association & - Teach, demonstrate and document rotation in drug chart at visit \\
\hline (ADEA) Clinical Guiding Principles for Subcuta- & - Rotation within one area rather than into a different area \\
\hline neous Injection Technique (2015) [26] & $\begin{array}{l}\text { - Divide into quadrants (abdomen) or halves (buttock or thigh), } 1 \text { quadrant/week } \\
\text { and move clockwise } \\
\text { - Site rotation grids - for pts forgetting injection sites }\end{array}$ \\
\hline $\begin{array}{l}\text { Indian FIT Recommendations for Best Practice } \\
\text { in Injection Technique (2017) [5] }\end{array}$ & $\begin{array}{l}\text { - Divide into quadrants (abdomen) or halves (buttock or thigh), use } 1 \text { quadrant/ } \\
\text { /week and move clockwise } \\
\text { - New injection site should be at least } 1-2 \mathrm{~cm} \text { apart from the previous site } \\
\text { - HCPs - review site rotation scheme at least once a year }\end{array}$ \\
\hline
\end{tabular}


Table 4. Available pen devices in the market

\begin{tabular}{|c|c|c|c|c|c|}
\hline Pen & Insulin types & $\mathrm{D} / \mathrm{R}$ & $\begin{array}{l}\text { Dosing } \\
\text { incre- } \\
\text { ments }\end{array}$ & Max dose & Colours/other features \\
\hline \multicolumn{6}{|c|}{ Novo Nordisk } \\
\hline NovoPen ${ }^{\circledR} 4$ & $\begin{array}{l}\text { NovoMix }^{\circledR} 30 ; \text { NovoRapid }^{\circledR} ; \\
\text { Levemir }^{\circledR} ; \text { Actrapid }^{\circledR} ; \\
\text { Mixtard }^{\circledR} 30 / 70 ; \text { Mixtard }^{\circledR} 50 / 50\end{array}$ & $\mathrm{R}$ & 1.0 & 60 & Silver or blue \\
\hline FlexPen $^{\circledR}$ & NovoMix $^{\circledR} 30 ;$ NovoRapid $^{\circledR}$; Levemir ${ }^{\circledR}$ & $\mathrm{D}$ & 1.0 & 60 & $\begin{array}{l}\left.\text { Blue (NovoMix }{ }^{\circledR} 30\right) \text {, orange } \\
\text { (NovoRapid }^{\circledR} \text { ), green (Levemir }{ }^{\circledR} \text { ) }\end{array}$ \\
\hline FlexTouch $^{\circledR}$ & Tresiba, Ryzodeg, Xultophy & $\mathrm{D}$ & 1 & $\begin{array}{l}50 \text { (Xultophy) } \\
80\end{array}$ & $\begin{array}{l}\text { Blue (Ryzodeg), green } \\
\text { (Tresiba), pink (Xultophy) }\end{array}$ \\
\hline \multicolumn{6}{|l|}{ Lilly } \\
\hline $\begin{array}{l}\text { Humapen }{ }^{\circledR} \\
\text { Savvio }^{\text {TM }}\end{array}$ & $\begin{array}{l}\text { Humalog }^{\circledR} ; \text { Humalog }{ }^{\circledR} \text { Mix } 25^{\circledR} \text {; Huma- } \\
\log ^{\circledR} \text { Mix } 50^{\circledR} ; \text { Humulin }{ }^{\circledR} \text { R; Humulin }{ }^{\circledR} \\
\text { NPH; Humulin }{ }^{\circledR} 30 / 70\end{array}$ & $\mathrm{R}$ & 1.0 & 60 & $\begin{array}{l}\text { Grey, blue, green, pink, } \\
\text { red and graphite }\end{array}$ \\
\hline $\begin{array}{l}\text { Humapen }^{\circledR} \\
\text { Luxura HD }^{\mathrm{TM}}\end{array}$ & $\begin{array}{l}\text { Humalog }^{\circledR} ; \text { Humalog }{ }^{\circledR} \text { Mix } 25^{\circledR} ; \text { Huma- } \\
\log ^{\circledR} \text { Mix } 50^{\circledR} ; \text { Humulin }^{\circledR} \text { R; Humulin }{ }^{\circledR} \\
\text { NPH; Humulin }{ }^{\circledR} 30 / 70\end{array}$ & $\mathrm{R}$ & 0.5 & 30 & Green \\
\hline Kwikpen ${ }^{\circledR}$ & $\begin{array}{l}\text { Humalog }^{\circledR} ; \text { Humalog }{ }^{\circledR} \text { Mix } 25^{\circledR} \text {; } \\
\text { Humalog }{ }^{\circledR} \text { Mix } 50^{\circledR}\end{array}$ & $\mathrm{D}$ & 1.0 & 60 & Grey \\
\hline \multicolumn{6}{|l|}{ Sanofi } \\
\hline Solostar ${ }^{\circledR}$ & Apidra $^{\circledR}$; Lantus ${ }^{\circledR}$; Toujeo ${ }^{\circledR}$ & $\mathrm{D}$ & 1.0 & 80 & $\begin{array}{l}\text { Grey }\left(\text { Lantus }{ }^{\circledR} \text { ), blue (Apidra }{ }^{\circledR} \text { ), }\right. \\
\text { grey and green (Toujeo }{ }^{\circledR} \text { ) }\end{array}$ \\
\hline AllStar ${ }^{\mathrm{TM}}$ & Apidra $^{\circledR} ;$ Lantus $^{\circledR}$ & $\mathrm{R}$ & 1.0 & 80 & Violet \\
\hline
\end{tabular}

D - disposable; $\mathrm{R}$ - reusable

/size, comfort/ease of use and ease of transport/storage), environmental factors (temperature stability, biodegradability/"green devices", availability of compatible insulins and availability of ancillary supplies), pragmatic factors (cost of device/insulin refills/needles, expected duration of insulin therapy with prescribed regimen and monthly dose requirement vis a vis capacity of device) and medication-counselling factors (time taken to reach, time taken to learn, risk of error in delivery and availability of post-prescription follow-up).

The modern pen devices have various advantages over the conventional insulin delivery methods such as user-friendliness, comfort of injection, higher accuracy specially at low doses, the flexibility of incorporating insulin injections into a busy lifestyle which may improve diabetes control with much less effort, while maintaining the quality of life for the diabetic patients $[43,44]$. Pen devices available in the market are summarized in Table 4.

In a past study on the accuracy and precision of lowdose insulin administration via various devices including NovoPen ${ }^{\circledR}$ (3.0 mL), BD-Mini Pen ${ }^{\circledR}(1.5 \mathrm{~mL})$, Humalog Pen $^{\circledR}(100 \mathrm{U} / \mathrm{mL}), 30 \mathrm{G}$ Precision Sure-Dose ${ }^{\circledR}$ Insulin Syringes, 30G BD Ultra-Fine II ${ }^{\circledR}$ Short Needle Syringes, and $\mathrm{H}$-TRON-plus $\mathrm{V} 100^{\circledR}$ insulin pump; the pen and pump devices were reported to be more accurate, and the pump to be more precise, than the syringes at the $1 \mathrm{U}$ and $2 U$ doses. Syringes were considered to be dangerously inaccurate clinically, at the $1 U$ dose (Figure 4) [44].

In a past study addressing dose accuracy of NovoPen ${ }^{\circledR} 4$ with respect to ISO tolerance limits [0.0-2.0 for a target dose of $1 \mathrm{U}, 28.5-31.5$ for $30 \mathrm{IU}$ and 57.0-63.0 for 60 U, SD: \pm 2.67 for each), NovoPen ${ }^{\circledR} 4$ was reported to be accurate before and after simulated lifetime use of 5475 injections in 5 years with mean dose of test medium delivered remained within the ISO tolerance limits at all doses tested and under conditions of mechanical and temperature stress (Figure 5) [45].

Comparison of minimum, medium, and maximum doses of FlexTouch ${ }^{\circledR}(1 / 40 / 80 \mathrm{U})$, KwikPen $^{\circledR}(1 / 30 / 60 \mathrm{U})$ and SoloSTAR ${ }^{\circledR}(1 / 40 / 80 \mathrm{U})$ in terms of dose accuracy in a past study revealed that FlexTouch ${ }^{\circledR}$ delivered all doses consistently, as demonstrated by low standard deviations [46]. FlexTouch ${ }^{\circledR}$ showed similar accuracy to KwikPen ${ }^{\circledR}$ at $1 \mathrm{U}$ and to SoloSTAR ${ }^{\circledR}$ at 40 and $80 \mathrm{U}$ and provided equivalent accuracy at medium and maximum doses with all tested pens, whereas it was significantly more accurate at delivering $1 \mathrm{U}$ of insulin than SoloSTAR ${ }^{\circledR}$ (Figure 6) [46]. 


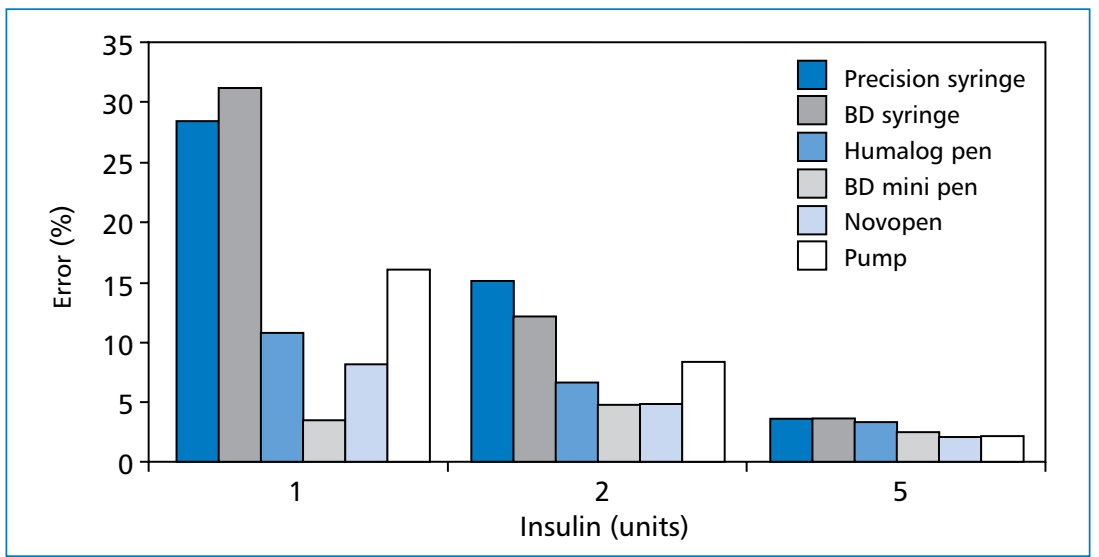

Figure 4. Accuracy and precision of low-dose insulin administration via different devices. Adapted from Keith K. et al. Clin Pediatr (Phila) 2004; 43 (1): 69-74

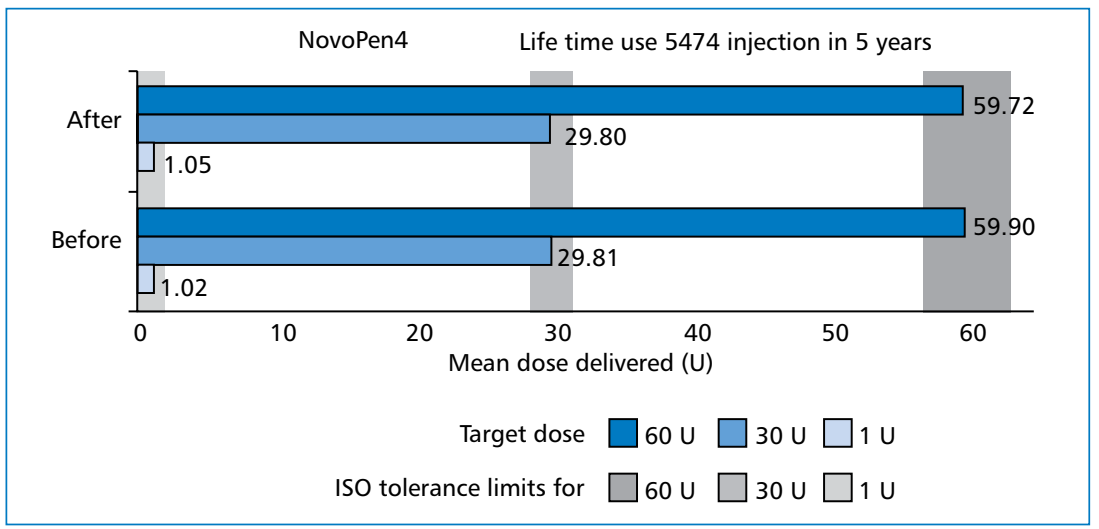

Figure 5. Dose accuracy and durability of the NovoPen ${ }^{\circledR} 4$ insulin delivery device. Adapted from Kristensen CM, Donsmark M. Clin Ther. 2009; 31 (12): 2819-2823

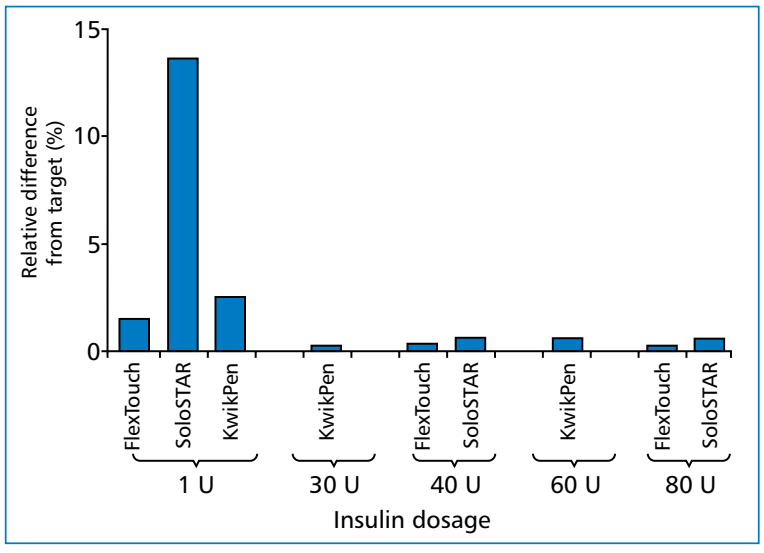

Figure 6. Mean relative percentage difference from target dose for FlexTouch, SoloSTAR, and KwikPen. Adapted from Wielandt JO. et al. J Diabetes Sci Technol. 2011; 5 (5): 1195-1199

Available guidelines consider insulin pens as the injection devices of choice due to shorter needle size, psychological advantages, convenience, accuracy and adherence as well as cost benefits due to treatment adherence (Table 5) [22-24, 26].

\section{Consensus statement on choice of device}

The expert panel recommends use of insulin pens over syringes for the convenience, ease of use, reduced fear of injections, greater treatment adherence and greater social acceptance. There are pen injectors dedicated to insulin preparations manufactured by different companies which may be used because they are compatible with insulin cartridges. However, Novo Pen ${ }^{\circledR} 4$ and Flex Touch ${ }^{\circledR}$ are recommended over other devices for the ease of use, accuracy and lower dose force vs. other pen devices.

\section{Consensus statement 4. Choice of device}

- Insulin pens are recommended over syringes for the convenience, ease of use

- Pen devices are preferred over syringes for reduced fear of injections and greater treatment adherence

- Pen devices are recommended over syringes as they offer greater social acceptance 
Table 5. Guideline recommendations on choice of device

\begin{tabular}{ll}
\hline Guideline & Recommendation \\
\hline $\begin{array}{l}\text { Canadian FIT Recommendations for Best } \\
\text { Practice in Injection Technique (2012) [22] }\end{array}$ & Insulin pens are the injection devices of choice due to shorter needle size \\
UK FIT Recommendations for Best Practice & Pen devices may have psychological advantages over syringes and therefore maybe \\
in Injection Technique (2015) [23] & more acceptable \\
$\begin{array}{l}\text { American Association of Diabetes Educators } \\
\text { (AADE) Strategies for Insulin Injection Therapy }\end{array}$ & \\
in Diabetes Self-Management (2011) [24] & \\
Australian Diabetes Educators Association & Convenience, accuracy and adherence \\
(ADEA) Clinical Guiding Principles for & \\
Subcutaneous Injection Technique (2015) [26] & \\
\hline
\end{tabular}

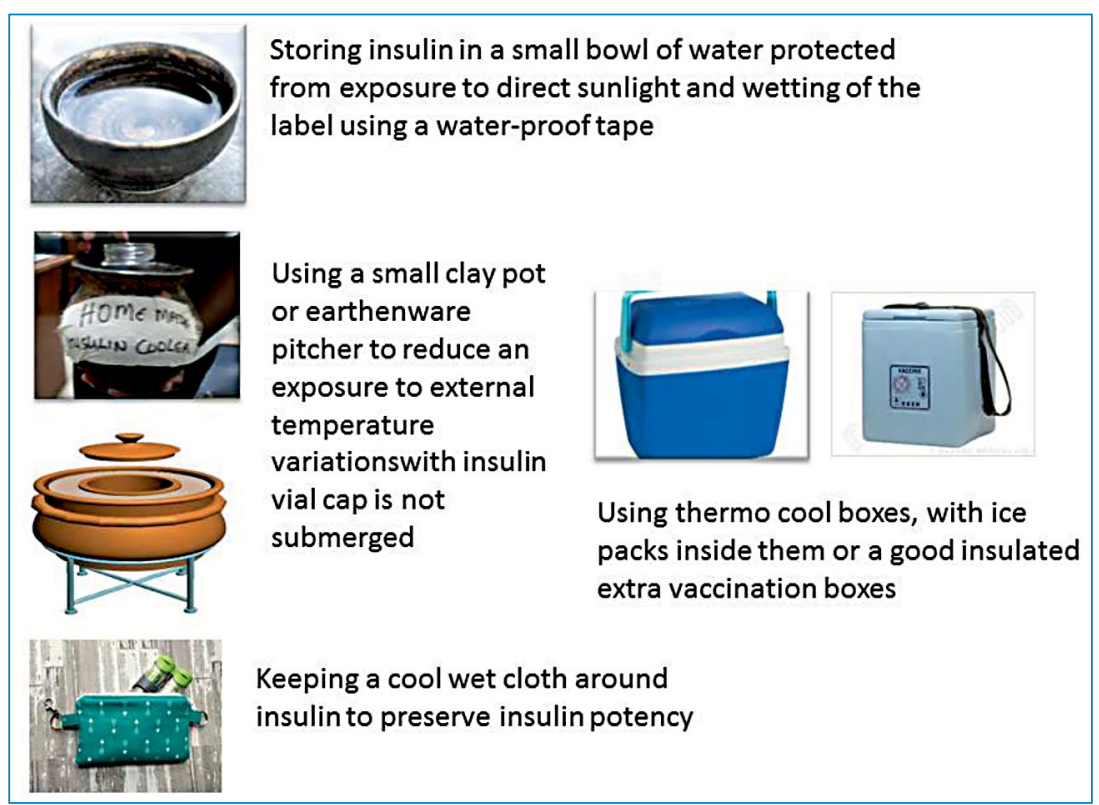

Figure 7. Improvised practical methods of storage in India — rural

\footnotetext{
- Novo Pen 4 and FlexTouch are recommended over other devices for the ease of use, accuracy and lower dose force vs other pen devices
}

\section{Storage of insulins}

For optimal effect, insulin need to be stored under refrigerated conditions, between 2 and $8^{\circ} \mathrm{C}$ as maintained below the freezer or in the butter compartment of most fridges, and be protected from light when vials or pens are unopened [47]. However, in India, up to $80 \%$ patients lack a good storage facility at home, while even in places where refrigerators are available, electrical supply may be erratic $[47,48]$. The insulin pen in use (insulin cartridge inside) can be stored at room temperature $\left(15-25^{\circ} \mathrm{C}\right)$ for 30 days [49]. However, the room temperature in many parts of India exceeds $25^{\circ} \mathrm{C}$ especially during summer season.

A survey in India showed approximately $75 \%$ of insulin to be stored at cool places, while cool places were not defined [8]. Additionally, the median time gap between taking out insulin vials from refrigerator and insulin injection was reported to be only $5 \mathrm{~min}$, which is considered likely to cause pain at the injection sites [8].

In another study performed in Puducherry, India, it was reported that storage of regular and biphasic insulin at $32^{\circ} \mathrm{C}$ and $37^{\circ} \mathrm{C}$ decreased the potency of insulin by 14 to $18 \%$ [50], emphasizing a need for patient education about the temperature and duration of storage of insulin vials to maintain adequate glycaemic control [47]. Nonetheless, improvised practical methods of insulin storage being implemented in rural India with limited facilities are as follows (Figure 7) [47]. 
- Storing insulin in a small bowl of water protected from exposure to direct sunlight and wetting of the label using a water-proof tape.

- Using a small clay pot or earthenware pitcher to reduce an exposure to external temperature variations with insulin vial cap is not submerged, and the labels with insulin name, date of opening, and date of expiry are preserved.

- Using thermo cool boxes, with ice packs inside them (replaced by frozen ones on weekly basis), as effective refrigeration devices for insulin that would keep the temperature within acceptable limits for many days.

- Using a good insulated extra vaccination boxes that can keep insulin stable for many days.

- Keeping a cool wet cloth around insulin to preserve insulin potency.

In fact, resource-poor mountainous areas such as Himalayas also pose significant challenges to insulin supply, storage and disposal where keeping insulin warm enough is an issue with temperature extremes range from $30^{\circ} \mathrm{C}$ in summer to $-20^{\circ} \mathrm{C}$ in winter as well as high indoor temperature during winter since members of the family stay together in a single room warmed by an iron-framed oven [51]. Hence persons living with diabetes on insulin therapy report insulin storage to be a major challenge during winter, since they are unable to store their insulin vial and pens in living rooms, because of extreme heat, and cannot use adjoining rooms, as night-time temperatures routinely fall below freezing point [51]. Accordingly, patients are advised by HCPs to store insulin vials and pens by wrapping them in two to three layers of warm woollen cloths, made of sheep wool, in wooden or steel cupboards, as the local method of storing foodstuffs [51].

Manufacturer instructions on storage of insulins are provided in Table 6 .

\section{Consensus statement on storage of insulin}

The expert panel recommends storage of injectable medicines in accordance with the manufacturer's instructions. Insulin should be discarded if it is past the expiry date, is open for more than a month, is discoloured or become cloudy. Insulin should be stored at refrigeration temperature $\left(2-8^{\circ} \mathrm{C}\right)$ until use, and at room temperature once in use, while it should never be frozen or exposed to extreme heat $\left(>30^{\circ} \mathrm{C}\right)$ for prolonged periods.

Consensus statement 5. Storage of insulin

- Injectable medicines should be stored according to the manufacturer's instructions
- Insulin should be discarded if it is past the expiry date on the bottle or if the vial has been open for more than a month

- If insulin is discoloured, lumps or flakes are seen, or clear insulin has turned cloudy, it must be discarded

- Insulin should be stored at refrigeration temperature $\left(2-8^{\circ} \mathrm{C}\right)$. Once in use, insulin may be stored at room temperature

- Insulin should never be frozen or exposed to extreme heat $\left(>30^{\circ} \mathrm{C}\right)$ for prolonged periods as this will affect insulin potency and alter its action

\section{Safety precautions, disposal}

\section{and complications}

Safety precautions and sharp disposal practice

Insulin pens are only approved for single-patient use and even though the needles were changed between uses, the patients were at risk due to possible biological contamination in the pen cartridges $[52,53]$. In accordance with widespread concern about disease transmission due to repeated instances of misuse of insulin pens, FDA, Institute for Safe Medication Practices (ISMP), and Centres for Disease Control (CDC) issues similar warnings against using the same insulin pen to administer insulin to multiple patients [53-55].

Improper sharp disposal practices among diabetes patients have been considered to be as high as $80-90 \%$ $[56,57]$.

ITQ 2014-2015 Study revealed a very large number of used diabetes sharps to still end up in the general community trash with use of a container specially made for used sharps by only $20.7 \%$ of patients and lack of a past training on proper disposal of sharps in $30 \%$ of patients [10]. Indian arm of ITQ 2014-2015 study revealed that almost $65 \%$ of patients were never trained on proper disposal of sharps [36].

Nearly 3 billion injections (83\% for curative purposes, $63 \%$ in an unsafe manner) is estimated to be administered annually in India [58], whereas the proper way of disposing sharps is one of the important, but often neglected component of proper injection techniques [58-60].

Accordingly, in a KAP study on disposal of sharp waste in India, $84.1 \%$ of diabetic patients were reported to discard the sharps directly into their household waste bins [61]. Authors also reported that $71 \%$ patients disposed at least 7 needles/week, 89\% patients disposed at least 7 lancets/week, whereas only $14.1 \%$ diabetes patients received education from their HCP regarding proper sharp disposal [61].

This seems notable given the higher likelihood of improper sharp disposal practice with lack of counselling from HCPs [60], along with a wide gap between 
Table 6. Manufacturer instructions on storage of insulins

\begin{tabular}{|c|c|c|c|}
\hline Insulin & Before first use & After opening & Shelf life \\
\hline $\begin{array}{l}\text { Novorapid } \\
\text { (vial \& penfill) }\end{array}$ & $2^{\circ} \mathrm{C}-8^{\circ} \mathrm{C}$ up to $\mathrm{ED}$ & Do not refrigerate, below $30^{\circ} \mathrm{C}$ for 4 weeks & 30 months \\
\hline Novomix 30 penfill & $2^{\circ} \mathrm{C}-8^{\circ} \mathrm{C}$ up to $\mathrm{ED}$ & Do not refrigerate, below $30^{\circ} \mathrm{C}$ for 4 weeks & 24 months \\
\hline Novomix 50 penfill & $2^{\circ} \mathrm{C}-8^{\circ} \mathrm{C}$ up to ED & Do not refrigerate, below $30^{\circ} \mathrm{C}$ for 4 weeks & 24 months \\
\hline Tresiba Flextouch & $2^{\circ} \mathrm{C}-8^{\circ} \mathrm{C}$ up to $\mathrm{ED}$ & Do not refrigerate, below $30^{\circ} \mathrm{C}$ for 8 weeks & 30 months \\
\hline $\begin{array}{l}\text { Ryzodeg Flextouch } \\
\text { \& penfill }\end{array}$ & $2^{\circ} \mathrm{C}-8^{\circ} \mathrm{C}$ up to $\mathrm{ED}$ & Do not refrigerate, below $30^{\circ} \mathrm{C}$ for 4 weeks & 30 months \\
\hline Levemir Flexpen & $2^{\circ} \mathrm{C}-8^{\circ} \mathrm{C}$ up to $\mathrm{ED}$ & Do not refrigerate, below $30^{\circ} \mathrm{C}$ for 6 weeks & 30 months \\
\hline Xultophy prefilled pen & $2^{\circ} \mathrm{C}-8^{\circ} \mathrm{C}$ up to $\mathrm{ED}$ & Do not refrigerate, below $30^{\circ} \mathrm{C}$ for 21 days & 24 months \\
\hline Insulatard & $2^{\circ} \mathrm{C}-8^{\circ} \mathrm{C}$ up to $\mathrm{ED}$ & Do not refrigerate, below $25^{\circ} \mathrm{C}$ for 4 weeks & \\
\hline Actrapid $40 \mathrm{IU}$ & $2^{\circ} \mathrm{C}-8^{\circ} \mathrm{C}$ up to $\mathrm{ED}$ & Do not refrigerate, below $25^{\circ} \mathrm{C}$ for 4 weeks & \\
\hline (vial \& flexpen) & & Flexpen below $30^{\circ} \mathrm{C}$ for 6 weeks & \\
\hline $\begin{array}{l}\text { Mixtard } 40 \text { IU } \\
\text { (vial \& flexpen) }\end{array}$ & $2^{\circ} \mathrm{C}-8^{\circ} \mathrm{C}$ up to $\mathrm{ED}$ & $\begin{array}{l}\text { Do not refrigerate, below } 25^{\circ} \mathrm{C} \text { for } 6 \text { weeks } \\
\text { Flexpen below } 30^{\circ} \mathrm{C} \text { for } 6 \text { weeks }\end{array}$ & \\
\hline $\begin{array}{l}\text { Lantus } \\
\text { (vial \& cartridge) }\end{array}$ & $\begin{array}{l}2^{\circ} \mathrm{C}-8^{\circ} \mathrm{C} \text { up to } \mathrm{ED} \\
\text { At RT for } 4 \text { weeks }\end{array}$ & $\begin{array}{l}\text { Refrigerated or RT for } 4 \text { weeks } \\
\text { Within pen device at RT for } 4 \text { weeks }\end{array}$ & 36 months \\
\hline $\begin{array}{l}\text { Humalog } \\
\text { (vial \& cartridge) }\end{array}$ & $\begin{array}{l}2^{\circ} \mathrm{C}-8^{\circ} \mathrm{C} \text { up to } \mathrm{ED} \\
\text { At RT for } 4 \text { weeks }\end{array}$ & $\begin{array}{l}\text { Refrigerated or RT for } 4 \text { weeks (vial) } \\
\text { Cartridge at RT }\end{array}$ & 36 months \\
\hline $\begin{array}{l}\text { Humalog Mix25, } \\
\text { Mix50 } \\
\text { (vial \& prefilled pen) }\end{array}$ & $\begin{array}{l}2^{\circ} \mathrm{C}-8^{\circ} \mathrm{C} \text { up to ED } \\
\text { At RT for } 4 \text { weeks (vial) } \\
\text { Pen at RT for } 10 \text { days }\end{array}$ & $\begin{array}{l}\text { Refrigerated or RT (below } 25^{\circ} \mathrm{C} \text { ) for } 4 \text { weeks (vial) } \\
\text { Pen at RT (below } 25^{\circ} \mathrm{C} \text { ) for } 10 \text { days }\end{array}$ & 36 months \\
\hline Basalog & $2^{\circ} \mathrm{C}-8{ }^{\circ} \mathrm{C}$ up to $\mathrm{ED}$ & Refill at RT (below $25^{\circ} \mathrm{C}$ ) up to 4 weeks & 24 months \\
\hline Apidra & $\begin{array}{l}2^{\circ} \mathrm{C}-8^{\circ} \mathrm{C} \text { up to ED } \\
\text { At RT for } 4 \text { weeks }\end{array}$ & $\begin{array}{l}\text { Refrigerated or RT (below } 25^{\circ} \mathrm{C} \text { ) for } 4 \text { weeks } \\
\text { Within pen device at RT (below } 25^{\circ} \mathrm{C} \text { ) for } 4 \text { weeks }\end{array}$ & \\
\hline Basaglar & $\begin{array}{l}2^{\circ} \mathrm{C}-8^{\circ} \mathrm{C} \text { up to } \mathrm{ED} \\
\text { At RT for } 4 \text { weeks }\end{array}$ & Do not refrigerate, below $30^{\circ} \mathrm{C}$ for 4 weeks & \\
\hline Insugen $50 / 50$ & $\begin{array}{l}2^{\circ} \mathrm{C}-8^{\circ} \mathrm{C} \text { up to } \mathrm{ED} \\
\text { At RT }\left(<25^{\circ} \mathrm{C}\right) \text { for } 6 \text { weeks }\end{array}$ & Do not refrigerate, below $25^{\circ} \mathrm{C}$ for 42 days & 36 months \\
\hline Eglucent & $2^{\circ} \mathrm{C}-8^{\circ} \mathrm{C}$ up to $\mathrm{ED}$ & Within pen device at RT (below $30^{\circ} \mathrm{C}$ ) for 4 weeks & 36 months \\
\hline Lupisulin & $2^{\circ} \mathrm{C}-8^{\circ} \mathrm{C}$ up to $\mathrm{ED}$ & RT (between $15^{\circ} \mathrm{C}-25^{\circ} \mathrm{C}$ ) for 2 weeks & \\
\hline $\begin{array}{l}\text { Insuman } \\
\text { (vials \& cartridge) }\end{array}$ & $2^{\circ} \mathrm{C}-8^{\circ} \mathrm{C}$ up to $\mathrm{ED}$ & $\begin{array}{l}\text { Vails can be refrigerated or RT (below } 25^{\circ} \mathrm{C} \text { ) for } 4 \text { weeks } \\
\text { Within pen device at RT (below } 25^{\circ} \mathrm{C} \text { ) for } 4 \text { weeks }\end{array}$ & 24 months \\
\hline
\end{tabular}

ED - expiry date; RT — room temperature

translation of research findings and their implementation in practice and poor adherence to established guidelines for sharp disposal practice in India [60, 62].

India is home to a huge diabetic population and concerns over sharp disposal practices in diabetes self-management are therefore important and should not be neglected given the likelihood of outbreaks of blood-borne infections and related adverse health and economic outcomes [60].

Current guidelines on safety precautions and disposal consider training of HCPs, caregivers and patients based on local regulations to be essential. The main recommendations include avoiding recapping, bending, or breaking a needle as well as disposing in household or public disposal system and using needle clipping device and puncture-resistant container (Table 7) $[5,22,23,25,26]$.

\section{Consensus statement on safety precautions and sharp disposal practice}

The expert panel recommends single person use of syringes and pen needles, patient's education about the safe disposal of their used sharps with reinforcement during subsequent visits, following local regulations regarding sharps disposal, avoiding disposal of sharps material into the public rubbish or household garbage.

Consensus statement 6. Safety precautions and sharp disposal practice

- Syringes and pen needles are for single person use only

- Pen devices and cartridges or vials are for single person use only, and must never be shared due to the risk of cross contamination even if the needle is changed

- Any HCP who is required to use a lifted skin fold must exhibit caution to avoid needle stick injury 
Table 7. Guidelines on safety precautions and sharp disposal practice

\begin{tabular}{|c|c|}
\hline Guideline & Recommendation \\
\hline Canadian FIT Recommendations for Best & - Training essential - based on local regulations \\
\hline Practice in Injection Technique (2012) [22] & $\begin{array}{l}\text { - Where available, a needle-clipping device can be used } \\
\text { - Needles should never be re-sheathed }\end{array}$ \\
\hline $\begin{array}{l}\text { UK FIT Recommendations for Best Practice } \\
\text { in Injection Technique (2015) [23] }\end{array}$ & $\begin{array}{l}\text { - Training of HCPs, caregivers and patients with reinforcement } \\
\text { - Based on local regulations } \\
\text { - Use needle clipping device } \\
\text { - Never dispose in household or public disposal system } \\
\text { - Pen devices without needle - can be disposed in house hold rubbish }\end{array}$ \\
\hline $\begin{array}{l}\text { American Association of Diabetes Educators } \\
\text { (AADE) Strategies for Insulin Injection Therapy } \\
\text { in Diabetes Self-Management (2011) [24] }\end{array}$ & None \\
\hline American Diabetes Association (ADA) Insulin & - Avoid recapping, bending, or breaking a needle \\
\hline Administration Guidelines (2004) [25] & $\begin{array}{l}\text { - Dispose according to local regulations } \\
\text { - Used sharps - puncture-resistant container }\end{array}$ \\
\hline $\begin{array}{l}\text { Australian Diabetes Educators Association } \\
\text { (ADEA) Clinical Guiding Principles for Subcuta- } \\
\text { neous Injection Technique (2015) [26] }\end{array}$ & $\begin{array}{l}\text { - Education extremely essential on disposal and safety } \\
\text { - Occupational safety } \\
\text { - Follow local regulations }\end{array}$ \\
\hline $\begin{array}{l}\text { Indian FIT Recommendations for Best Practice } \\
\text { in Injection Technique (2017) [5] }\end{array}$ & $\begin{array}{l}\text { - Adequate training on safety and disposal - patients and caregivers } \\
\text { - Sharps containers in every ICU, ward and nursing station } \\
\text { - Used needles or syringes - puncture proof box/safety box/strong cardboard/ } \\
\text { /glass container } \\
\text { - Label the box as biohazard and handover to health-care facility } \\
\text { - NACO guidelines - gives safe disposal methods }\end{array}$ \\
\hline
\end{tabular}

- People with diabetes are taught about the safe disposal of their used sharps with reinforcement during subsequent visits

- Local regulations regarding sharps disposal must be followed

- Sharps material must not be disposed of into the public rubbish or household garbage

- Empty pen devices can be disposed of in the normal household refuse when the needle is removed

\section{Complications of insulin injections}

ITQ 2014-2015 Study revealed higher rates of unexplained hypoglycaemia and glucose variability in those with $\mathrm{LH}$, injecting into $\mathrm{LH}$, incorrect rotation of sites and needle reuse [10].

According to ITQ 2014-2015 data, LH was highly prevalent $(30.8 \%)$, while associated with consumption of $10.1 \mathrm{IU}$ more insulin daily, $0.55 \%$ higher $\mathrm{HbA}_{1 \mathrm{c}}$ levels, higher rates of unexplained hypoglycaemia and glycaemic variability as well as with incorrect rotation of injection sites, use of smaller injection zones and reuse of pen needles [38].

Indian ITQ revealed $21.9 \%$ of Indian patients had nurse-confirmed $\mathrm{LH}$ with almost equivalent risk across sites (8.7-10.1\%) except buttocks (0.0\%) [36]. Inject- ing into LH was consistently reported to be associated with delayed or erratic insulin absorption, potentially worsening the diabetes management $[63,64]$. In this regard, it should be noted that Indian patients with $\mathrm{LH}$ were found not to inject into $\mathrm{LH}$ lesions as frequently as in ROW (35.0\% vs. $56.0 \%$ ), while $53 \%$ were unaware of the reasons underlying this practice with convenience and pain less frequently cited by Indian patients compared to ROW (17.0 vs. 38.0\%) [36].

Although none is evidence-based, several approaches have been recommended in treatment of $\mathrm{LH}$ such as changing the insulin formulation (e.g., aspart to lispro, or lispro to glulisine, etc.), changing injection sites, or shifting to CSII and possibly cortisone injection [36].

ITQ 2014-2015 data revealed that $60.2 \%$ of patients experience bleeding and bruising (never: $50.8 \%$, sometimes: $41.5 \%$, often: $7.3 \%$ [ [38]. In Indian ITQ, $41.4 \%$ of Indian patients reported bleeding or bruising from their injection sites (never: $37.7 \%$, sometimes: $53.6 \%$, often: $7.8 \%$ ) [36].

Injection using a $4 \mathrm{~mm}$ needle at $90^{\circ}$ is considered to deliver insulin into subcutaneous tissue for $>99.5 \%$ of times with minimal risk of intradermal (ID) injections. Majority of injections at four commonly-used sites with 
Table 8. IM injection risk according to needle length and injection angle at injection sites [32]

\begin{tabular}{|c|c|c|c|c|c|}
\hline \multirow{2}{*}{$\begin{array}{l}\text { Needle length, } \\
\text { injection angle }\end{array}$} & & \multicolumn{4}{|c|}{ Risk of IM injection (\%) } \\
\hline & & Thigh & Arm & Abdomen & Buttock \\
\hline \multirow[t]{2}{*}{$4 \mathrm{~mm}$} & $90^{\circ}$ & 1.6 & 1.0 & 0.3 & 0.1 \\
\hline & $45^{\circ}$ & NA & NA & NA & NA \\
\hline \multirow[t]{2}{*}{$5 \mathrm{~mm}$} & $90^{\circ}$ & 4.7 & 3.1 & 1.1 & 0.5 \\
\hline & $45^{\circ}$ & NA & NA & NA & NA \\
\hline \multirow[t]{2}{*}{$6 \mathrm{~mm}$} & $90^{\circ}$ & 10.0 & 7.0 & 2.8 & 1.3 \\
\hline & $45^{\circ}$ & 2.2 & 1.3 & 0.4 & 0.2 \\
\hline \multirow[t]{2}{*}{$8 \mathrm{~mm}$} & $90^{\circ}$ & 25.0 & 19.5 & 9.7 & 5.5 \\
\hline & $45^{\circ}$ & 8.0 & 5.5 & 2.1 & 1.0 \\
\hline \multirow[t]{2}{*}{$12.7 \mathrm{~mm}$} & $90^{\circ}$ & 63.0 & 55.0 & 38.0 & 26.9 \\
\hline & $45^{\circ}$ & 34.0 & 27.0 & 14.6 & 8.8 \\
\hline
\end{tabular}

a 4-5 $\mathrm{mm}$ needle at $90^{\circ}$ would be delivered into the subcutaneous tissue with $<2 \%$ risk of intramuscular (IM) injections [30, 32].

When inserted $90^{\circ}$ without pinch-up, the most commonly used needle worldwide $(8 \mathrm{~mm})$ has estimated IM risks of $25 \%$ and $9.7 \%$, respectively, in the thigh and abdomen, versus $1.6 \%$ and $0.1 \%$, respectively, with a $4 \mathrm{~mm}$ needle. $A 45^{\circ}$ insertion reduces, but does not eliminate, IM risk with longer needles [32].

Risk of IM injection in considered to be higher in arm and thigh injections and further increase with increasing needle size, from $1 \%(4 \mathrm{~mm})$ to $55 \%$ (12.7 mm, $27 \%$ for $\left.45^{\circ}\right)$ in the arm and from $1.6 \%(4 \mathrm{~mm})$ to $63 \%$ $\left(12.7 \mathrm{~mm}, 34 \%\right.$ for $\left.45^{\circ}\right)$ in the thigh (Table 8) [32].

ITQ 2014-2015 data revealed that pain was associated with larger needle size and needle reuse and increase as a function of the number of times the needle is reused [38]. Pain was commonly associated with bleeding, injecting through clothes, injecting insulin while it is still cold, $\mathrm{LH}$, injecting into $\mathrm{LH}$, incorrect site rotation, higher $\mathrm{HbA}_{1 \mathrm{c}}$ levels, lower $\mathrm{BMI}$, younger age, and higher total daily dose of insulin [38].

Indian ITQ revealed that $50 \%$ of Indian injectors had pain on injection [36], while authors also emphasized that patient awareness of injection discomfort depends on several factors such as needle length, needle diameter, injection context and apprehension of HCPs $[36,65,66]$.

Past studies addressing injection pain reported no impact of injection speed $(150,300$, and $450 \mu \mathrm{l} / \mathrm{s}$; equivalent to $15-45 \mathrm{IU} / \mathrm{s}$ of $\mathrm{U} 100$ insulin) on pain [67], whereas more pain with higher injection volume ( $\geq 1200 \mu \mathrm{l}$ or $120 \mathrm{IU}$ of U100 insulin) [67-69] and selection of thigh compared to abdomen as an injection site [67]. Nonetheless, it was concluded that injection pain is mild enough to be acceptable to most of patients particularly with today's very thin, short needles [36, 67].

Current guidelines recommend regular inspection and palpation of sites, rotation of sites and avoiding needle reuse and injecting in $\mathrm{LH}$ to prevent $\mathrm{LH}$; recommend reassurance for avoid occasional bleeding and bruising and review of technique for frequent bleeding and bruising, use shorter needles and avoid IM injection to prevent bleeding and bruising, recommend avoiding injection through clothes to prevent intradermal injection, avoiding $12.7 \mathrm{~mm}$ needles and injecting at 45 degree and using lifted skin fold or injecting abdomen in slim patients to prevent IM injection; and recommend injecting at room temperature, using distraction methods, using needles of shorter length and smaller diameter and a new needle at each injection, allowing topical alcohol (if used) to evaporate before injection, inserting needle in a quick smooth movement and injecting slowly and removing at same angle with not changing the direction of needle during insertion and withdrawal to prevent pain (Table 9) [5, 22-26].

\section{Consensus statement on complications of insulin injections}

For $\mathrm{LH}$, the expert panel recommends patient education about examining injection sites to detect $\mathrm{LH}$ and avoiding injection into the hypertrophic and atrophic areas. HCP inspection and palpation of injection sites at each visit, use of site rotation and non-reuse of needles are also recommended to prevent $\mathrm{LH}$ which should be ruled out as a cause of poor glycaemic control, hypoglycaemia and high glycaemic variability. For bleeding and bruising the expert panel recommends reassuring patients about no significant impact of occasional bruising or bleeding at site on insulin action, whereas a review of injection technique for frequent 
Table 9. Guideline recommendations about complications of insulin injections

\begin{tabular}{|c|c|}
\hline Guideline & Recommendation \\
\hline $\begin{array}{l}\text { Canadian FIT Recommendations for Best } \\
\text { Practice in Injection Technique (2012) [22] }\end{array}$ & $\begin{array}{l}\text { Lipohypertrophy } \\
\text { - Avoid injection in LH, hair roots, scars, moles and other skin abnormalities } \\
\text { - Use needles of shorter length and smaller diameter } \\
\text { - To prevent LH - site rotation, use larger injection zones, new needle } \\
\text { - Inspect and palpate site at each visit, patient education } \\
\text { - Dose reduction - if site changed from LH site to normal tissue } \\
\text { Bleeding and bruising } \\
\text { - Frequent bleeding and bruising - review injection technique } \\
\text { - Occasional bleeding and bruising - reassurance that won't affect insulin action } \\
\text { Intradermal injection } \\
\text { - Avoid injection through clothes to avoid intradermal injection } \\
\text { IM injection } \\
\text { - } 12.7 \text { mm needles not recommended - risk of IM injection } \\
\text { - Slim patients - inject at } 45^{\circ} \text { to avoid IM injection } \\
\text { Pain } \\
\text { - Inject at room temperature - to avoid pain, relax apprehensive patient }\end{array}$ \\
\hline $\begin{array}{l}\text { UK FIT Recommendations for Best Practice } \\
\text { in Injection Technique (2015) [23] }\end{array}$ & $\begin{array}{l}\text { Lipohypertrophy } \\
\text { - Patient education, inspect site at each visit } \\
\text { - To prevent LH - site rotation, avoid reuse of needles } \\
\text { - Reduce dose - if shifting from LH to normal tissue } \\
\text { Bleeding and bruising } \\
\text { - To avoid bleeding - avoid IM injection } \\
\text { - Occasional bleeding and bruising - reassurance } \\
\text { - Frequent bleeding and bruising - review technique } \\
\text { Pain } \\
\text { - Keep injectable at room temperature } \\
\text { - Use needles of shorter length and smaller diameter } \\
\text { - Use a new needle at each injection } \\
\text { - Insert needle in a quick smooth movement } \\
\text { - Inject slowly and ensure plunger or thumb button is fully depressed } \\
\text { - Remove at same angle and keep hand steady } \\
\text { IM injection } \\
\text { - Use lifted skin fold in slim limbs and abdomen }\end{array}$ \\
\hline $\begin{array}{l}\text { American Association of Diabetes Educators } \\
\text { (AADE) Strategies for Insulin Injection Therapy } \\
\text { in Diabetes Self-Management (2011) [24] }\end{array}$ & $\begin{array}{l}\text { Lipohypertrophy } \\
\text { - Patient education, inspect site at each visit } \\
\text { - To prevent LH - site rotation } \\
\text { Pain } \\
\text { - Inject at room temperature } \\
\text { - Allow topical alcohol (if used) to evaporate before injection } \\
\text { - Relax muscles at the site } \\
\text { - Using distraction methods } \\
\text { - Quickly penetrate the skin } \\
\text { - Don't change direction of needle during insertion or withdrawal } \\
\text { - Don't reuse needles } \\
\text { - Use injection device that puts pressure on skin around the site } \\
\text { - Apply pressure for 5-8 seconds after injection, without rubbing, if really painful } \\
\text { IM injection } \\
\text { - Use smaller size needles }\end{array}$ \\
\hline
\end{tabular}


Table 9 (cont.). Guideline recommendations about complications of insulin injections

\begin{tabular}{|c|c|}
\hline Guideline & Recommendation \\
\hline $\begin{array}{l}\text { American Diabetes Association (ADA) Insulin } \\
\text { Administration Guidelines (2004) [25] }\end{array}$ & $\begin{array}{l}\text { Lipohypertrophy } \\
\text { - To prevent LH - site rotation, avoid reuse of needles } \\
\text { Bleeding and bruising } \\
\text { - Frequent bleeding and bruising - review technique } \\
\text { - Apply pressure for } 5-8 \text { seconds without rubbing } \\
\text { - Frequent glucose monitoring } \\
\text { Pain } \\
\text { - Injecting insulin at room temperature } \\
\text { - Making sure no air bubbles remain in the syringe before injection } \\
\text { - Wait for topical alcohol (if used) to evaporate } \\
\text { - Keep muscles in the injection area relaxed } \\
\text { - Penetrating the skin quickly } \\
\text { - Don't change direction of needle during insertion or withdrawal } \\
\text { - Don't reuse needles } \\
\text { IM injection } \\
\text { - Use short needles specially in slim patients and children } \\
\text { - Inject at } 45^{\circ} \text { (especially in thigh) }\end{array}$ \\
\hline $\begin{array}{l}\text { Australian Diabetes Educators Association } \\
\text { (ADEA) Clinical Guiding Principles for Subcuta- } \\
\text { neous Injection Technique (2015) [26] }\end{array}$ & $\begin{array}{l}\text { Lipohypertrophy } \\
\text { - Inspect and palpate injection sites for nodules, multiple pricks over small area } \\
\text { - Ask about the frequency and method of site rotation and needle reuse } \\
\text { - Longer diabetes duration and insulin use, frequency of injecting - higher risk of LH } \\
\text { - Document location and size of LH } \\
\text { - Rotate injection sites, use new needle } \\
\text { Intradermal injection } \\
\text { - Injection at } 90^{\circ} \text { with } 4 \mathrm{~mm} \text { needle } \\
\text { IM injection } \\
\text { - Inject into the abdomen or buttocks } \\
\text { - Avoid sites with little SC tissue such as arms and thighs } \\
\text { - Use shorter needle lengths, lift skin fold, Insertion needle at } 45^{\circ} \text { angle } \\
\text { Pain } \\
\text { - Injecting insulin at room temperature rather than when cold } \\
\text { - If using alcohol to clean the skin, injecting only after this has dried } \\
\text { - Use a new needle, shorter length and smaller diameter } \\
\text { - Penetrate skin quickly with needle and inject slowly } \\
\text { - Don't change direction of needle during insertion and withdrawal }\end{array}$ \\
\hline $\begin{array}{l}\text { Indian FIT Recommendations for Best Practice } \\
\text { in Injection Technique (2017) [5] }\end{array}$ & $\begin{array}{l}\text { Lipohypertrophy } \\
\text { - Regular inspection and palpation of sites } \\
\text { - Rotation of sites, no needle reuse } \\
\text { - Use larger injection surface areas } \\
\text { - Do not inject into LH sites } \\
\text { - Reduce dose of insulin in habitual LH site injections if shifting to normal SC tissue } \\
\text { - Rule out LH - poor glycaemic control, hypoglycaemia, and high glycaemic } \\
\text { variability } \\
\text { Bleeding and bruising } \\
\text { - Frequent bleeding and bruising - review injection technique } \\
\text { - Use shorter needles } \\
\text { IM injection } \\
\text { - Use } 6 \text { mm needles } \\
\text { - Avoid syringe needles in < } 6 \text { years old children and exceptionally thin adults } \\
\text { (BMI < } 19 \text { kg/m²) } \\
\text { Pain } \\
\text { - Inject at room temperature, use new needles, concentrated insulin if large dose } \\
\text { - Neutral pH insulin if pain with acidic insulin } \\
\text { - Penetrate skin quickly, don't move needle after insertion }\end{array}$ \\
\hline
\end{tabular}


bruising or bleeding, and use of shorter needles for less frequent bleeding and bruising and consideration of the likelihood of IM injection for frequent bleeding and bruising with glycaemic variability. The expert panel recommends injecting into the abdomen or buttocks and use of shorter needle lengths, lifted skin fold and insertion of the needle at $45^{\circ}$ to prevent IM injection and avoiding injection through clothing to prevent intradermal injection. For pain, the expert panel recommends considering all factors contributing to the perception of pain such as individual perception, needle length and diameter, injection technique and IM injection and recommends use of short and narrow-gauge $(4-5-\mathrm{mm} \times 32 \mathrm{G})$ insulin pen needles, injecting at room temperature and allowing topical alcohol (if used) to evaporate before injection, relaxing muscles at the site when injecting, using distraction methods, not reusing needles and penetrating skin quickly without changing needle direction during insertion or withdrawal to prevent pain.

Consensus statement 7. Complications of insulin injections

\section{Lipohypertrophy}

- Individuals should be taught to examine their own injection sites and how to detect lipohypertrophy

- Best current preventative and therapeutic strategies for lipohypertrophy - site rotation and non-reuse of needles

- HCP should inspect and palpate sites at each visit ideally in a standing position

- Avoid injection into the hypertrophic and atrophic areas

- When switching injection from areas of LH to normal tissue, insulin dose reduction may be required (guided by glucose measurement)

- Rule out LH as a cause of poor glycaemic control, hypoglycaemia and high glycaemic variability

\section{Bleeding and bruising}

- Reassure patients - insulin action is not affected by occasional bruising or bleeding at site

- Frequent bruising or bleeding - warrants a review of injection technique

- Less frequent bleeding and bruising - with use of shorter needles

- Frequent bleeding and bruising with glycaemic variability may point towards IM injection

\section{IM injection}

- Inject into the abdomen or buttocks

- Avoid sites with thin subcutaneous tissue such as arms and thighs

- Consider different techniques according to sites chosen: shorter needle lengths, lifted skin fold and insertion of the needle at $45^{\circ}$ angle
Pain

- Factors contributing to pain - perceptual sensitivity, needle length and diameter, injection technique, and intramuscular injection

- Less pain with short and narrow-gauge $(4-5-\mathrm{mm} \times 32 \mathrm{G})$ insulin pen needles

- Inject at room temperature and allow topical alcohol (if used) to evaporate before injection

- Relax muscles at the site when injecting, and using distraction methods

- Penetrate skin quickly and don't change needle direction during insertion or withdrawal

- Don't reuse needles, and use pressure applying injection device around the injection site

Intradermal injections

- Intra-dermal injection - appearance of white area when withdrawing needle indicates insulin has not been injected deeply enough

- Avoid injection through clothing to prevent intradermal injection

\section{Conclusion}

This expert panel based consensus statement provides a simple and easily implementable practical educational guideline for HCPs and patients to optimize insulin injection practices (preparation and selection of injection sites, site rotation, selection of device, storage of insulins, safety precautions, sharp disposal practice and complications) in accordance with recent advances in device manufacturing, newer research findings, and updated international guidelines as well as widespread concerns about neglected safety precautions such as single-patient use of pens and appropriate sharp disposal practices. This seems important given the overall findings from ITQ studies that highlight the need of easy to use practical guidance to optimize insulin injection practices as well as findings specific to Indian cohort such as suboptimal rates for patient training on injection practice and routine check of injection sites by HCPs at every visit.

Accordingly, the expert panel recommendations regarding insulin injection practices provided in this consensus statement emphasize:

- injecting into a clean site after inspection and palpation and with use of soap and water for cleaning rather than disinfecting the skin;

- selection of abdomen (offering the most consistent/fastest absorption) as followed by thighs and buttocks as the appropriate injection sites for adults, whereas potential of thigh and buttocks to be more appropriate for NPH due to slowest 
absorption from these sites along with no sitespecific alterations in absorption rate of basal insulin analogues;

- teaching an easy-to-follow and structured site rotation scheme to patients from the onset of injection therapy and checking injection sites routinely at each visit;

- preferring use of insulin pens (particularly Novo Pen ${ }^{\circledR} 4$ and Flex Touch ${ }^{\circledR}$ for dose accuracy) over syringes for the convenience, ease of use, reduced fear of injections, greater treatment adherence and greater social acceptance;

- storing injectable medicines in accordance with the manufacturer's instructions, with storing insulin at refrigeration temperature $\left(2-8^{\circ} \mathrm{C}\right)$ until use, and at room temperature once in use by preventing exposure to extreme cold or heat;

- adhering to single person use of syringes and pen needles and providing patient education on safe sharp disposal practices per local regulations with avoiding disposal of sharps material into the public rubbish or household garbage and reinforcement during subsequent visits;

- inspection and palpation of injection sites by HCPs at each visit to identify LH which should be ruled out as a cause of poor glycaemic control, hypoglycaemia and high glycaemic variability, and use of site rotation, non-reuse of needles, providing patient education about examining injection sites to detect $\mathrm{LH}$ and to avoid injecting into the hypertrophic and atrophic areas to prevent $\mathrm{LH}$; reassuring patients about no significant effect of occasional bruising or bleeding at site on insulin action, whereas a review of injection technique, encouraging use of shorter needles and considering the likelihood of intramuscular injection and consequent glycaemic variability for frequent bruising or bleeding; injecting into the abdomen or buttocks and use of shorter needle lengths, lifted skin fold and insertion of the needle at $45^{\circ}$ to prevent intramuscular injection and avoiding injection through clothing to prevent intradermal injection; considering all factors contributing to the perception of pain such as individual sensitivity, needle length and diameter, injection technique and intramuscular injection, use of short and narrow-gauge $(4-5-\mathrm{mm} \times 32 \mathrm{G})$ insulin pen needles, injecting at room temperature and allowing topical alcohol (if used) to evaporate before injection, using distraction methods, not reusing needles and penetrating skin quickly without changing needle direction during insertion or withdrawal to prevent pain.

\section{Declaration of interest}

The authors have no competing interests.

This research did not receive any specific grant from funding agencies in the public, commercial, or not-for-profit sectors.

\section{REFERENCES}

1. International Diabetes Federation. IDF Diabetes Atlas Update 2017. 8th ed. Available from: http://www.diabetesatlas.org.

2. World Health Organization. Global Report on Diabetes 2016. (NLM Classification: WK 810) 2016. Available from: http://www.apps. who.int/iris/bitstream/10665/204871/1/9789241565257_eng.pdf.

3. Akhtar S, Dhillon P. Prevalence of diagnosed diabetes and associated risk factors: Evidence from the large-scale surveys in India. J Soc Health Diabetes. 2018; 5(1): 28-36, doi: 10.4103/23210656.194001.

4. Frid A, Hirsch L, Gaspar R, et al. Scientific Advisory Board for the Third Injection Technique Workshop. New injection recommendations for patients with diabetes. Diabetes Metab. 2010; 36 Suppl 2: S3-18, doi: 10.1016/S1262-3636(10)70002-1, indexed in Pubmed: 20933208.

5. Tandon N, Kalra S, Balhara YP, et al. Forum for injection technique and therapy expert recommendations, India: the Indian recommendations for best practice in insulin injection technique, 2017. Indian J Endocrinol Metab. 2017; 21(4): 600-617, doi: 10.4103/ ijem.IJEM 97 17, indexed in Pubmed: 28670547.

6. Gururaj Setty S, Crasto W, Jarvis J, et al. New insulins and newer insulin regimens: a review of their role in improving glycaemic control in patients with diabetes. Postgrad Med J. 2016; 92(1085): 152-164, doi: 10.1136/postgradmedj-2015-133716, indexed in Pubmed: 26842973.

7. De Coninck C, Frid A, Gaspar R, et al. Results and analysis of the 2008-2009 Insulin Injection Technique Questionnaire survey. J Diabetes. 2010; 2(3): 168-179, doi: 10.1111/j.17530407.2010.00077.x, indexed in Pubmed: 20923482

8. Patil M, Sahoo J, Kamalanathan $S$, et al. Assessment of insulin injection techniques among diabetes patients in a tertiary care centre. Diabetes Metab Syndr. 2017; 11 Suppl 1: S53-S56, doi: 10.1016/j.dsx.2016.09.010, indexed in Pubmed: 27614866.

9. Kapoor U, Ramasamy G, Selvaraj K, et al. Does one-to-one demonstration with insulin pads by health-care providers improves the insulin administration techniques among diabetic patients of a Tertiary Care Teaching Hospital in South India? Indian J Endocrinol Metab. 2016; 20(6): 767-771, doi: 10.4103/2230-8210.192904, indexed in Pubmed: 27867877.

10. Frid $A H$, Hirsch $\sqcup$, Menchior AR, et al. Worldwide injection technique questionnaire study: population parameters and injection practices. Mayo Clin Proc. 2016; 91(9): 1212-1223, doi: 10.1016/j. mayocp.2016.06.011, indexed in Pubmed: 27594185.

11. Davidson JA. New injection recommendations for patients with diabetes. Diabetes Metab. 2010; 36 Suppl 2: S2, doi: 10.1016/ S1262-3636(10)70001-X, indexed in Pubmed: 20933207.

12. Siminerio L, Kulkarni K, Meece J, et al. Strategies for insulin injection therapy in diabetes self-management. Diabetes Educ. 2011; 37: 1-10.

13. Dolinar R. The importance of good insulin injection practices in diabetes management. US Endocrinology. 2009; 5(1): 49-52, doi: 10.17925/use.2009.05.1.49.

14. Brod M, Alolga SL, Meneghini L. Barriers to initiating insulin in type 2 diabetes patients: development of a new patient education tool to address myths, misconceptions and clinical realities. Patient. 2014; 7(4): 437-450, doi: 10.1007/s40271-014-0068-x, indexed in Pubmed: 24958464. 
15. Okazaki K, Goto M, Yamamoto T, et al. Barriers and facilitators in relation to starting insulin therapy in type 2 diabetes. Diabetes. 1999; 48: SA319-SA319.

16. Jha $S$, Panda $M$, Kumar $S$, et al. Psychological insulin resistance in patients with type 2 diabetes. J Assoc Physicians India. 2015; 63(7): 33-39, indexed in Pubmed: 26731825.

17. Davel H, Berg GI, Allie R, et al. Injection technique guidelines for diabetes: sharp and to the point. J Endocrinol Metab Diabetes S Afr. 2014; 19(1): 8-13, doi: 10.1080/16089677.2014.11073595.

18. Tandon N, Kalra S, Balhara YP, et al. Forum for injection technique (FIT), India: the Indian recommendations 2.0, for best practice in insulin injection technique, 2015. Indian J Endocrinol Metab. 2015; 19(3): 317-331, doi: 10.4103/2230-8210.152762, indexed in Pubmed: 25932385.

19. Kalra S, Mithal A, Sahay R, et al. Indian injection technique study: population characteristics and injection practices. Diabetes Ther. 2017; 8(3): 637-657, doi: 10.1007/s13300-017-0243-x, indexed in Pubmed: 28289893.

20. Poudel RS, Shrestha S, Piryani RM, et al. Assessment of insulin injection practice among diabetes patients in a tertiary healthcare centre in Nepal: a preliminary study. J Diabetes Res. 2017; 2017: 8648316, doi: 10.1155/2017/8648316, indexed in Pubmed: 29333459.

21. Ji J, Lou Q. Insulin pen injection technique survey in patients with type 2 diabetes in mainland China in 2010. Curr Med Res Opin. 2014; 30(6): 1087-1093, doi: 10.1185/03007995.2014.895711, indexed in Pubmed: 24552616.

22. Berard L, Desrochers F, Husband A, MacNeill G, Roscoe R; Canadian Diabetes Association FIT Board. Canadian Forum of Injection techniques (FIT) Recommendations for Best Practice in Injection Technique, 2012 https://www.bd.com/resource.aspx?IDX=25063.

23. Hicks D, Adams D, Diggle J, Gelder C. FIT Board. UK Forum of Injection techniques (FIT) Recommendations for Best Practice in Injection Technique, 2015 http://www.fit4diabetes.com/files/6714/4293/6325/FIT_Injection_Technique_ Recommendations_3rd_Edition_lo_res.pdf.

24. American Association of Diabetes Educators (AADE) Strategies for Insulin Injection Therapy in Diabetes Self-Management, 2011 https://www.bd.com/resource.aspx?IDX=25123.

25. American Diabetes Association. Insulin administration. Diabetes Care. 2004; 27(Suppl 1): S106-S109.

26. Frid $A H$, Hirsch $\amalg$, Menchior $A R$, et al. Worldwide injection technique questionnaire study: population parameters and injection practices. Mayo Clin Proc. 2016; 91(9): 1212-1223, doi: 10.1016/j. mayocp.2016.06.011, indexed in Pubmed: 27594185.

27. Hildebrandt $P$, Hildebrandt P. Skinfold thickness, local subcutaneous blood flow and insulin absorption in diabetic patients. Acta Physiol Scand Suppl. 1991; 603(4): 41-45, indexed in Pubmed: 1789128.

28. Hildebrandt P. Subcutaneous absorption of insulin in insulindependent diabetic patients: influence of species, physicochemical properties of insulin and physiological factors. Dan Med Bull. 1991; 38: 337-346.

29. Gagnon-Auger M, du Souich P, Baillargeon JP, et al. Dose-dependent delay of the hypoglycemic effect of short-acting insulin analogs in obese subjects with type 2 diabetes: a pharmacokinetic and pharmacodynamic study. Diabetes Care. 2010; 33(12): 25022507, doi: 10.2337/dc10-1126, indexed in Pubmed: 20841613.

30. Gibney MA, Arce $\mathrm{CH}$, Byron KJ, et al. Skin and subcutaneous adipose layer thickness in adults with diabetes at sites used for insulin injections: implications for needle length recommendations. Curr Med Res Opin. 2010; 26(6): 1519-1530, doi: 10.1185/03007995.2010.481203, indexed in Pubmed: 20429833.

31. Karges B, Boehm BO, Karges W. Early hypoglycaemia after accidental intramuscular injection of insulin glargine. Diabet Med. 2005; 22(10): 1444-1445, doi: 10.1111/j.1464-5491.2005.01654.x, indexed in Pubmed: 16176210.

32. Hirsch L, Byron K, Gibney M. Intramuscular risk at insulin injection sites - measurement of the distance from skin to muscle and rationale for shorter-length needles for subcutaneous insulin therapy. Diabetes Technol Ther. 2014; 16(12): 867-873, doi: 10.1089/dia.2014.0111, indexed in Pubmed: 25329935.

33. Wood L, Wilbourne J, Kyne-Grzebalski D. Administration of insulin by injection. Pract Diabetes Int. 2002; 19(2): S1-S4.

34. Ahern J, Mazur ML. Mazur ML. Site rotation Diabetes Forecast. 2001; 54: 66-68.

35. Yadav S, Parakh A. Insulin therapy. Indian Pediatr. 2006; 43(10): 863-872, indexed in Pubmed: 17079829.

36. Kalra S, Mithal A, Sahay $R$, et al. Indian injection technique study: injecting complications, education, and the health care professional. Diabetes Ther. 2017; 8(3): 659-672, doi: 10.1007/ s13300-017-0244-9, indexed in Pubmed: 28289892.

37. Davis ED, Chesnaky P. Site rotation. Taking insulin. Diabetes Forecast. 1992 ; 45: 54-56.

38. Frid $A H$, Hirsch $\sqcup$, Menchior AR, et al. Worldwide injection technique questionnaire study: injecting complications and the role of the professional. Mayo Clin Proc. 2016; 91(9): 1224-1230, doi: 10.1016/j.mayocp.2016.06.012, indexed in Pubmed: 27594186.

39. Photographs courtesy of Lourdes Saez-de Ibarra and Ruth Gaspar, Diabetes Nurses and Specialist Educators from La Paz Hospital, Madrid, Spain.

40. Lumber T. Tips for site rotation. When it comes to insulin, where you inject is just as important as how much and when. Diabetes Forecast. 2004; 57(7): 68-70, indexed in Pubmed: 15295808.

41. Thatcher $\mathrm{G}$. Insulin injections. The case against random rotation. Am J Nurs. 1985; 85(6): 690-692, indexed in Pubmed: 3890543.

42. Spollett G, Edelman SV, Mehner P, et al. Improvement of insulin injection technique: examination of current issues and recommendations. Diabetes Educ. 2016; 42(4): 379-394, doi: 10.1177/0145721716648017, indexed in Pubmed: 27216036.

43. Baruah MP. Insulin pens: the modern delivery devices. J Assoc Physicians India. 2011; 59 Suppl: 38-40.

44. Keith K, Nicholson D, Rogers D. Accuracy and precision of low-dose insulin administration using syringes, pen injectors, and a pump. Clin Pediatr (Phila). 2004; 43(1): 69-74, doi: 10.1177/000992280404300109, indexed in Pubmed: 14968895.

45. Kristensen CM, Donsmark M. Dose accuracy and durability of the NovoPen 4 insulin delivery device before and after simulation of 5 years of use and under various stress conditions. Clin Ther. 2009; 31(12): 2819-2823, doi: 10.1016/j.clinthera.2009.12.005, indexed in Pubmed: 20110021.

46. Wielandt JO, Niemeyer M, Hansen MR, et al. FlexTouch: a prefilled insulin pen with a novel injection mechanism with consistent high accuracy at low- (1 U), medium- (40 U), and high- (80 U) dose settings. J Diabetes Sci Technol. 2011; 5(5): 1195-1199, doi: 10.1177/193229681100500525, indexed in Pubmed: 22027317.

47. Kalra S, Kalra B. Storage of insulin in rural areas. J Acad Med Sci. 2012; 2(2): 88-89, doi: 10.4103/2249-4855.118669.

48. Kumar KM, Saboo B, Rao PV, et al. Type 1 diabetes: Awareness, management and challenges: Current scenario in India. Indian J Endocrinol Metab. 2015; 19(Suppl 1): S6-S8, doi: 10.4103/22308210.155339, indexed in Pubmed: 25941655.

49. Frid AH, Kreugel G, Grassi G, et al. New insulin delivery recommendations. Mayo Clin Proc. 2016; 91(9): 1231-1255, doi: 10.1016/j.mayocp.2016.06.010, indexed in Pubmed: 27594187.

50. Vimalavathini R, Gitanjali B. Effect of temperature on the potency \& pharmacological action of insulin. Indian J Med Res. 2009; 130(2): 166-169, indexed in Pubmed: 19797814.

51. Mokta JK, Kalra S. Insulin storage in the Upper Himalayas. Rural Remote Health. 2014; 14(3): 2983, indexed in Pubmed: 25238754.

52. Herdman ML, Larck C, Schliesser SH, et al. Biological contamination of insulin pens in a hospital setting. Am J Health Syst Pharm. 2013; 70(14): 1244-1248, doi: 10.2146/ajhp120728, indexed in Pubmed: 23820462.

53. Kuehn BM. FDA warns against shared insulin pens. JAMA. 2009; 301(15): 1527, doi: 10.1001/jama.2009.497, indexed in Pubmed: 19366765. 
54. Institute for Safe Medication Practices. Reuse of insulin pen for multiple patients risks transmission of bloodborne disease. www. ismp.org/newsletters/acutecare/articles/20090212-2.asp.

55. Centers for Disease Control and Prevention. Clinical reminder: insulin pens must never be used for more than one person. www.cdc.gov/injectionsafety/clinicalreminders/insulin-pens.html.

56. Costello J, Parikh A. The sticking point: diabetic sharps disposal practices in the community. J Gen Intern Med. 2013; 28(7): 868-869, doi: 10.1007/s11606-013-2350-3, indexed in Pubmed: 23377844.

57. Govender D, Ross A. Sharps disposal practices among diabetic patients using insulin. S Afr Med J. 2012; 102(3 Pt 1): 163-164, indexed in Pubmed: 22380912.

58. Chaturvedi S, Arora NK, Lakshman M, et al. Study Group. Injection practices in India. South East Asia J Public Health. 2012; 1: 189-200.

59. Kalra S, Balhara $Y$, Baruah M, et al. Addendum 2: forum for injection technique, India. Indian J Endocrinol Metab. 2014; 18(6): 800-803, doi: 10.4103/2230-8210.141344.

60. Majumdar A, Sahoo J, Roy G, et al. Improper sharp disposal practices among diabetes patients in home care settings: Need for concern? Indian J Endocrinol Metab. 2015; 19(3): 420-425, doi: 10.4103/2230-8210.152792, indexed in Pubmed: 25932402.

61. Singh AP, Chapman RS. Knowledge, attitude and practices (KAP) on disposal of sharp waste, used for home management of type-2 diabetes mellitus in New Delhi, India. J Health Res. 2011; 25(3): 135-139.

62. Tharkar S, Devarajan A, Barman $\mathrm{H}$, et al. How far has translation of research been implemented into clinical practice in India? Are the recommended guidelines adhered to? Int J Diabetes Mellit. 2015; 3(1): 25-30, doi: 10.1016/j.ijdm.2011.01.002.

63. Chowdhury TA, Escudier V. Poor glycaemic control caused by insulin induced lipohypertrophy. BMJ. 2003; 327(7411): 383-384, doi: 10.1136/bmj.327.7411.383, indexed in Pubmed: 12919996.

64. Johansson UB, Amsberg S, Hannerz L, et al. Impaired absorption of insulin aspart from lipohypertrophic injection sites. Diabetes Care. 2005; 28(8): 2025-2027, indexed in Pubmed: 16043749.

65. Brady K, Avner JR, Khine H. Perception and attitude of providers toward pain and anxiety associated with pediatric vaccine injection. Clin Pediatr (Phila). 2011; 50(2): 140-143, doi: 10.1177/0009922810384721, indexed in Pubmed: 21098527.

66. Diamond S, Matok I. Pharmacists' anticipated pain compared to experienced pain associated with insulin pen injection and fingertip lancing. Canadian Journal of Diabetes. 2011; 35(3): 282-286, doi: 10.1016/s1499-2671(11)53012-6.

67. Heise T, Nosek L, Dellweg $S$, et al. Impact of injection speed and volume on perceived pain during subcutaneous injections into the abdomen and thigh: a single-centre, randomized controlled trial. Diabetes Obes Metab. 2014; 16(10): 971-976, doi: 10.1111/ dom.12304, indexed in Pubmed: 24720741.

68. Anderson G, Meyer D, Herrman CE, et al. Tolerability and safety of novel half milliliter formulation of glatiramer acetate for subcutaneous injection: an open-label, multicenter, randomized comparative study. J Neurol. 2010; 257(11): 1917-1923, doi: 10.1007/s00415-010-5779-x, indexed in Pubmed: 20953791.

69. Jørgensen JT, Rømsing J, Rasmussen $M$, et al. Pain assessment of subcutaneous injections. Ann Pharmacother. 1996; 30(7-8): 729-732, doi: 10.1177/106002809603000703, indexed in Pubmed: 8826549. 